\title{
AUTECOLOGY OF VIBRIO VULNIFICUS AND VIBRIO PARAHAEMOLYTICOS IN TROPICAL WATERS
}

by

Susan Rivera, Tomás Lugo, and Terry C. Hazen*

Microbial Ecology Laboratory

Department of Biology

College of Natural Sciences

University of Puerto Rico

Rio Piedras, Puerto Rico 00931

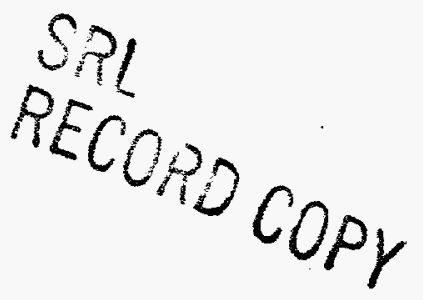

* Present address: E. I. du Pont de Nemours and Company

Savannah River Laboratory

Aiken, South Carolina 29808

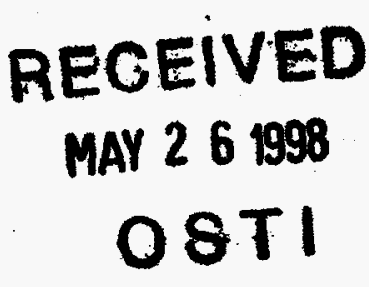

\section{DISCLAIMER}

This report was prepared as an account of work sponsored by an agency of the United States Government. Neither the United States Gnvernment nor any agency thereof, nor any of their employees, makes any warranty, express or implied, or assumes any legal liability or responsibility for the accuracy, completeness, or usefulness of any information, apparatus, product, or process disclosed, or represents that its use would not infringe privately owned rights. Reference herein to any specific commercial product, process, or service by trade name, trademark, manufacturer, or otherwise does not necessarily constitute or imply its endorsement, recommendation, or favoring by the United States Government or any agency thereof. The views and opinions of authors expressed herein do not necessarily state or reflect those of the United States Government or any agency thereof.

This paper was prepared in connection with work done under Contract No. DE-AC09-76SR00001 with the U.S. Department of Energy. By acceptance of this paper, the publisher and/or recipient acknowledges the U.S. Government's right to retain a nonexclusive, royalty-free license in and to any copyright covering this paper, along with the right to reproduce and to authorize others to reproduce all or part of the copyrighted paper. 


\section{DISCLAIMER}

Portions of this document may be illegible in electronic image products. Images are produced from the best available original document. 


\title{
Autecology of Vibrio vulnificus and - Vibrio parahaemolyticus in Tropical Waters
}

\author{
Susan Rivera, Tomás Lugo, and Terry C. Hazen*† \\ Microbial Ecology Laboratory \\ Department of Biology \\ College of Natural Sciences \\ University of Puerto Rico \\ Río Piedras, Puerto Rico 00931
}

Running Title: Marine Vibrio spp. in the tropical waters

*correspondent author

$\dagger$ Present address: E. I. du Pont de Nemours \& Company, Inc.

Savannah River Laboratory

Environmental Sciences Division

Aiken, South Carolina 29808 
: ABSTRACT

Water and shellfish samples collected from estuaries, mangroves, : and beaches along the coast of Puerto Rico were examined for Vibrio

¿ulnificus and Vibrio parahaemolyticus. An array of water quality

¿parameters were also measured simultaneous with bacteria sampling. Both species of vibrio were associated with estuary and mangrove ${ }^{3}$ locations, and neither was isolated from sandy beaches. Densities of $\underline{V}$. vulnificus were negatively correlated with salinity, $10-15 \mathrm{ppt}$ being optimal. $\underline{\text { Varahaemolyticus }}$ was isolated from sites with salinities between 20 and $35 \mathrm{ppt}$, the highest densities occurring at 20

$\therefore$ ppt. Densities of Vibrio spp. and $\underline{V}$. parahaemolyticus for a tropical estuary surpassed those reported for temperate estuaries by several - orders of magnitude. Both densities of total Vibrio spp. and $\underline{V}$. parahaemolyticus in the water were directly related to densities of fecal coliforms, unlike $\underline{V}$. vulnificus. The incidence of $\mathrm{ONPG}(+)$ strains among sucrose(-) Vibrio spp. served as an indicator of the frequency of $\underline{\mathrm{V}}$. vulnificus in this group. More than $63 \%$ of the $\underline{\mathrm{V}}$. vulnificus isolated ' were pathogenic. $\underline{V}$. vulnificus and $\underline{V}$. parahaemolyticus occupy clearly $\therefore$ separate niches within the tropical estuarine-marine ecosystem. 


\section{INTRODUCTION}

Temperature and salinity seem to play important roles in : regulating densities of $\underline{V}$. vulnificus and $\underline{V}$. parahaemolyticus $(14,16$, इ32). Increased water temperature appears to favor the survival and growth of $\underline{V}$. vulnificus and $\underline{V}$. parahaemolyticus in the environment. The peak recovery of $\underline{V}$. vulnificus in sites around Galveston Island was

${ }^{z}$ in September when water temperature had been above $25^{\circ} \mathrm{C}$ for 4

months. Densities of $\underline{V}$. vulnificus rapidly decreased as water temperature decreased in the fall (16). $\underline{V}$. vulnificus was also isolated more often in two Florida estuaries when water temperature was greater than $17^{\circ} \mathrm{C}$ and in a greater proportion of samples over $29^{\circ} \mathrm{C}$ (32).

Kaneko and Colwell (14) found the incidence of $\underline{V}$. parahaemolyticus

- was directly related to season in the Chesapeake Bay. A temperature of $14^{\circ}$ to $19^{\circ} \mathrm{C}$ was critical for the isolation of the organism from the water column and sediments. When water temperatures reached $28.5^{\circ} \mathrm{C}$, $\underline{V}$. parahaemolyticus counts up to $5.7 \times 10^{3} \mathrm{CFU} / 10 \mathrm{~g}$ sediment were observed. Yet, during the winter, counts of less than $1 \mathrm{CFU} / \mathrm{g}$ were typical (14).

$\therefore \quad$ Low salinities have also been positively correlated with increased $\because$ densities of $\underline{V}$. vulnificus and $\underline{V}$. parahaemolyticus. Off Galveston Island,

$\therefore 47 \%$ of the samples from sites having salinities of $<16 \mathrm{ppt}$, yielded

${ }^{23} \mathrm{~V}$. vulnificus (16). Negative correlations have also been observed

${ }^{24}$ between salinity and the incidence of lactose fermenting Vibrio spp.

25 isolated from seawater, sediment, plankton, and animal samples (23, 
24). Along the Louisiana coast, $\underline{V}$. vulnificus was not recovered from : freshwater nor brackish water when salinities were below 1 ppt (28). However, in a study conducted in two Florida estuaries, $\underline{V}$. vulnificus : was isolated more frequently in waters with a salinity $>17 \mathrm{ppt}$ and in a s higher proportion of samples with salinities $>23 \mathrm{ppt}$ (32). Sayler et al. s(30) also attributed a low frequency of $\underline{V}$. parahaemolyticus isolation to the low salinity of their study sites. Colwell et al. (10) observed

${ }^{3} \mathrm{~V}$. parahaemolyticus in waters with salinities from 8 to $20 \mathrm{ppt}$. Yet, Horie et. al. (13) reported densities as high as $1.5 \times 10^{5}$ cells/liter in water having a salinity of $5 \mathrm{ppt}$. Aiso et al. (1) showed that 5 to $10 \mathrm{ppt}$ was the optimal salinity for $\underline{V}$. parahaemolyticus growth at $20^{\circ} \mathrm{C}$ while : $30 \mathrm{ppt}$ was optimal for growth at $37^{\circ} \mathrm{C}$.

The tropical climate of Puerto Rico, where year-round - temperature averages $28^{\circ} \mathrm{C}$, would seem ideal for Vibrio spp. and therefore Vibriosis. In temperate areas, $85 \%$ of $\underline{V}$. vulnificus infections occurred in the warm months of the year (5). High evaporation rates and low rainfall increase estuary and coastal salinities in shellfish harvesting waters. Thus higher salinities and temperature should be optimal for $\underline{V}$. vulnificus and $\underline{V}$. parahaemolyticus growth in tropical areas. In addition, raw oysters are quite often consumed at road side stands in Puerto Rico where refrigeration is nonexistent. As observed by Oliver (22), the bacterium grows quite rapidly in unchilled raw $\therefore$ oysters.

24 The importance of Vibrio spp. in recent seafood poisoning cases 25 has been well established $(5,8)$. Blake et al. (5) reported that twenty- 
four of 39 cases of disease caused by $\underline{V}$. vulnificus were associated with

$\therefore$ food ingestion. Forty-six percent of these food ingestion cases were

fatal. The source of contamination in $83 \%$ of these cases was identified

: as raw oysters. Outbreaks of gastroenteritis caused by

$5 \underline{V}$. parahaemolyticus are also invariably associated with the

6 consumption of seafood (8). Considering that for 1986, Puerto Rico had

? 54,569 municipal clinic and hospital reported cases of gastroenteritis

${ }^{3}$ with a specific attack rate of more than $200 / 100,000$ population (27), it

$\xi$ is conceivable that Vibrio spp. are responsible for a many of these cases.

This study examines the distribution, and pathogenicity of

$\underline{V}$. parahaemolyticus and $\underline{V}$. vulnificus in shellfish and near shore

$\therefore$ coastal waters of Puerto Rico.

(This study was part of the M.S. thesis of S. Rivera at the

$\therefore$ University of Puerto Rico, Río Piedras, Puerto Rico, 1987.) 


\section{MATERIALS AND METHODS}

Study sites. Luquillo Beach (LB) and the Río Mameyes Estuary $\therefore$ are on the northeast coast of the island at $18^{\circ} 15^{\prime} \mathrm{N}, 65^{\circ} 45^{\prime} \mathrm{W}$, see

${ }^{5}$ Carrillo et al. (7) for details (Fig. 1). Torrecilla Lagoon (TL) (18 $20^{\prime} \mathrm{N}$, $\left.{ }^{5} 66^{\circ} 00^{\prime} \mathrm{W}\right)$ is near San Juan, and is a recreational center and a shellfish harvesting area. It receives incoming currents from the Atlantic Ocean

${ }^{8}$ and is surrounded by mangroves. Palo Seco Channel (PSC) is on the ${ }^{\prime}$ northern coast of the island at $18^{\circ} 20^{\prime} \mathrm{N}, 66^{\circ} 10^{\prime} \mathrm{W}$ and drains into the Atlantic Ocean. Bayamon River Channel Estuary (BRC) has a total length of $6.9 \mathrm{~km}$ and drains into Ensenada de Boca Vieja cove. It is located on the northern coast of the island at $18^{\circ} 25^{\prime} \mathrm{N}, 66^{\circ} 09^{\prime} \mathrm{W}$. This channel is

- a site of sewage effluent discharge. Ensenada de Boca Vieja (EBV) is a - protected cove adjacent to San Juan Bay located at $18^{\circ} 27^{\prime} \mathrm{N}, 66^{\circ} 45^{\prime} \mathrm{W}$, see Biamón and Hazen (3), and Valdés-Collazo et al., (33) for details. Bayamon River Estuary (BR) is on the northern coast of the island at $18^{\circ}$ $25^{\prime} \mathrm{N}, 66^{\circ} 10^{\prime} \mathrm{W}$. It drains into San Juan Bay and is surrounded by mangroves. It is also a site of limited shellfish harvesting. Mandry

' Channel (MC) is near Humacao at $18^{\circ} 9^{\prime} \mathrm{N}, 65^{\circ} 46^{\prime} \mathrm{W}$. It flows across low coastal lands receiving the running waters from farming and $\therefore$ pasture lands.

2 Water quality. In situ measurements were taken of salinity

23 and both air and water temperature. Salinity was measured by using a

${ }^{24}$ hand refractometer (model 10419, American Optical, Buffalo, N.Y.).

25 Collected samples were analyzed in the laboratory for turbidity, $\mathrm{pH}$, 
chlorophyll $a$, nitrites plus nitrates, phosphates, total phosphorus, and : dissolved oxygen. These were determined using Standard Methods for Water and Wastewater Analysis (2).

Bacteriological procedures. Sterile, one liter bottles were

s filled with water for bacteria counts. Collected shellfish were placed in

sterile Whirl-Pak bags (Nasco International, Fort Wilkinson, Wis.). All samples were transported to the laboratory for analysis within 3-5 h.

3 Total cell counts were determined by direct count (AODC) methods using

acridine orange (12). Percent activity was established by calculating the ratio of red cells to the total cell number (18). Density of actively respiring cells was determined using the INT reduction technique of Zimmermann et al. (37). All techniques are as described previously (3, $7,11,17,25)$. Densities of fecal coliforms were estimated by membrane - filtration (2).

Densities of Vibrio spp. were determined by filtering with a 0.45 $\mu \mathrm{m}$ pore size, $47 \mathrm{~mm}$ diameter, HA-type membrane filter (Millipore Corp., Bedford, Mass.). After filtration, filters were placed on TCBS medium (Difco, Detroit, Mich.) in sterile tight fitting petri dishes and incubated at $35^{\circ} \mathrm{C}$ for $24 \mathrm{~h}$. When incubation was completed, total Vibrio spp. were estimated by counting all colonies. Sucrose positive $\therefore$ Vibrio spp. were counted as colonies appearing yellow. Sucrose

$\therefore$ negative Vibrie spp. were counted as colonies appearing blue or green.

23 Random sucrose negative colonies were picked and transferred to

24 marine agar medium (Difco). All isolates were tested for oxidase

is production using the API Oxidase kit (Analytab Products, Plainview, 
N.Y.), and ONPG hydrolysis using ONPG diffusion disks (Difco) or API2 20E strips (Analytab). All oxidase positive organisms were subjected to a battery of biochemical tests using API-20E strips (Analytab) with 20

sppt marine salts diluent (Instant Ocean, Aquarium Systems, Eastlake, S Ohio) and incubation at $22^{\circ} \mathrm{C}(19)$. Isolates with typical reactions were

${ }^{5}$ identified as presumptive $\underline{V}$. vulnificus and $\underline{V}$. parahaemolyticus and subjected to further tests in order to confirm their identity. Sensitivity

${ }^{8}$ to 2-4 diamino 6-7 di-isopropyl pteridine phosphate $(\mathrm{O} / 129)$ was

determined using the disk diffusion method. Presumptive $\underline{V}$. vulnificus sensitive to both $150 \mu \mathrm{g}$ and $10 \mu \mathrm{g}$ of $\mathrm{O} / 129$ were tested further as were presumptive $\underline{V}$. parahaemolyticus isolates sensitive to $150 \mu \mathrm{g}$ but resistant to $10 \mu \mathrm{g}$ of $\mathrm{O} / 129$. Salt tolerance tests were conducted by adding $0 \%, 7 \%$, and $10 \% \mathrm{NaCl}$ to modified salt water yeast extract agar - MSWYE (26). Isolates growing in $7 \% \mathrm{NaCl}$ but not $10 \% \mathrm{NaCl}$, with typical biochemical reactions for $\underline{V}$.parahaemolyticus were identified accordingly. Those isolates unable to grow in either $7 \%$ or $10 \% \mathrm{NaCl}$ with typical biochemical reactions for $\underline{\mathrm{V}}$. vulnificus were tested for sensitivity to penicillin (10 $\mathrm{U})$ and colistin $(10 \mu \mathrm{g})$. Isolates resistant to ${ }^{7}$ colistin and sensitive to penicillin were identified as $\underline{V}$. vulnificus.

20 $\mathrm{V}$. vulnificus (ATCC 27562) and $\underline{\mathrm{V}}$. parahaemolyticus (ATCC 17802)

$\therefore$ were used as controls for all tests and media.

22 Identification of $\underline{\mathrm{V}}$. parahaemolyticus and $\underline{\mathrm{V}}$. vulnificus was

23 further confirmed with a slide flocculation procedure using core

${ }^{24}$ flagellar antiserum against $\underline{V}$. vulnificus and, both flagellar and core 25 
flagellar antiserum against $\underline{V}$. parahaemolyticus donated by Dr. Ronald : Siebeling, Louisiana State University (31).

Pathogenicity. Isolates positively identified as $\underline{\mathrm{V}}$. vulnificus

- were used to prepare an active inoculum containing $10^{9}$ cells $\mathrm{ml}^{-1}$

${ }^{5}$ grown in Brain Heart Infusion broth (Difco) $1.5 \% \mathrm{NaCl}$ and incubated for

$518 \mathrm{~h}$ at $35^{\circ} \mathrm{C}$. One-half $\mathrm{ml}$ of this inoculum was injected intraperitoneally to 6-8 week old $\mathrm{AKR} / \mathrm{J}$ female white mice to determine strain pathogenicity (26). Pathogenicity of

$\underline{V}$. parahaemolyticus isolates was determined by the Kanagawa test (20). Fresh human blood was used with Wagatsuma's agar $(9,34)$ to determine the isolates ability to cause B-hemolysis of erithrocytes.

$\therefore$ Data analysis. One factor analysis of variance (ANOVA) without replication was used to test differences between sites using programs $\therefore$ developed for a Macintosh computer. Multiple correlation was used to determine relationships between density and water quality parameters. Any statistical probability less than 0.05 was considered significant (36). 


\section{RESULTS}

Representative water quality data for each site is given in Table 1. A total of 409 sucrose negative isolates were examined (Table 2). The 5 nine study sites examined ranged in AODC density from $9.6 \times 10^{5}$ to 1.7

$510^{7}$ cells $\mathrm{ml}^{-1}$ (Fig. 2). The AODC measurement correlated positively ' with viable count densities of both Vibrio spp. and fecal coliforms

(Table 3). Total bacterial densities also held strong positive correlations

with concentrations of phosphate and total phosphorus in the environment. The percent activity of the bacterial population at the various sites ranged from 14.4 to 74.7 (Fig. 2). Bacterial densities as measured by both direct count and all viable count methods were negatively correlated with percent activity (Table 3). Although the percentage of respiring cells in the bacterial community was much lower than the percent activity for all sites examined (Fig. 2), both measurements were significantly positively correlated.

The percentage that Vibrio spp. represented in the total bacterial community was very small for all sites (Table 2). Yet, Vibrio spp. share with the entire bacterial community a significant positive correlation with phosphates and total phosphorus concentrations in the the water. When densities of fecal coliforms increased so did the density of Vibrio $\therefore$ spp. as did the proportion of Vibrio spp. in the total bacterial

$2 j$ community (Fig. 2). Densities of Vibrio spp. and the percentage of ${ }_{24}$ Vibrio spp. in the total bacterial community were negatively correlated 25 with dissolved oxygen. Densities of Vibrio spp. by site ranged from 16.9 
CFU ml-1 to $1.5 \times 10^{6} \mathrm{CFU} \mathrm{ml}^{-1}$ (Table 2). For shellfish, densities of

Vibrio spp. by site, ranged from $5.2 \times 10^{3} \mathrm{CFU} \mathrm{g}^{-1}$ to $1.5 \times 10^{4} \mathrm{CFU} \mathrm{g}^{-1}$.

: Densities of Vibrio spp. were not correlated with salinity, while both

- sucrose(-) Vibrio spp. $\mathrm{ml}^{-1}$ and the percentage of sucrose(-) Vibrio spp.

swere negatively correlated with salinity. The percentage of sucrose(-)

${ }^{5}$ Vibrio spp. making up the vibrio population decreased with increasing

salinity of the sites (Table 2). The percentage of sucrose $(+)$ Vibrio spp.

${ }^{8}$ was not correlated with salinity and was generally higher than that of

${ }^{\xi}$ sucrose(-) Vibrio spp. Densities of sucrose(-) Vibrio spp. at the various

$\therefore$ sites ranged from $3.24 \mathrm{CFU} \mathrm{ml}^{-1}$ to $12.76 \times 10^{5} \mathrm{CFU} \mathrm{ml}^{-1}$ (Table 2). In shellfish, densities of sucrose(-) Vibrio spp. by site ranged from $1.3 \mathrm{x}$ $210^{3} \mathrm{CFU} \mathrm{g}^{-1}$ to $2.7 \times 10^{3} \mathrm{CFU} \mathrm{g}^{-1}$.

The densities of sucrose(-) Vibrio spp. showed a highly significant

- positive correlation with densities of ONPG $(+)$ Vibrio spp. (Table 3 ).

Both the density of ONPG(+) Vibrio spp. and the percentage of sucrose(-) Vibrio spp. made up of ONPG(+) vibrios were significantly negatively correlated with salinity (Table 3 ). A significant difference by site was $=$ observed for ONPG(+) Vibrio spp. $\mathrm{ml}^{-1}$. Sites with increasing salinity - showed decreasing percentages of ONPG $(+)$ Vibrio spp. Densities of $\therefore \mathrm{ONPG}(+)$ Vibrio spp. for the various sites ranged from $0.83 \mathrm{CFU} \mathrm{ml}^{-1}$ to 2: $5.94 \times 10^{5} \mathrm{CFU} \mathrm{ml}^{-1}$ (Table 2). Densities of ONPG(+) Vibrio spp. in 22 shellfish ranged from $208 \mathrm{CFU} \mathrm{g}^{-1}$ to $449 \mathrm{CFU} \mathrm{g}^{-1}$ by site.

23 As shown in Table 2, densities of $\underline{V}$. vulnificus by site ranged from $2438 \mathrm{CFU} 100 \mathrm{ml}^{-1}$ to $4,124 \mathrm{CFU} 100 \mathrm{ml}^{-1}$. Both the highest densities and 25 the highest frequencies of isolation of $\underline{V}$. vulnificus were obtained at 
salinities of 10 and 15 ppt. $\underline{V}$. vulnificus was never isolated from sandy : beach, seawater samples (sites LB and EBV). Bayamon River estuary (BR) and the upper Río Mameyes estuary (URM) possess extreme - salinities of $32.2 \mathrm{ppt}$ and $1.7 \mathrm{ppt}$ respectively (Table 1). At these sites

$s$ the lowest frequencies of isolation were observed, representing less

s than $4 \%$ of sucrose negative Vibrio spp. In Torrecilla Lagoon (TL), for both water and shellfish, $\underline{V}$. vulnificus was isolated only when salinities ${ }^{8}$ were between 20 and 25 ppt. The percentage of $\underline{\mathrm{V}}$. vulnificus isolates

${ }^{y}$ which proved lethal to mice showed an even higher significant negative correlation with salinity than did all $\underline{V}$. vulnificus isolates (Table 3 ). 'At sites TL and BR where salinities were highest none of the $\underline{V}$. vulnificus : isolated proved pathogenic. Overall, $46 \%$ of $\underline{\mathrm{V}}$. vulnificus isolates were ipathogenic. It is interesting to note that densities of fecal coliforms - were not significantly correlated with densities of $\underline{V}$. vulnificus. Significant negative correlations were observed between densities of V. vulnificus and; phosphates, total phosphorus, and $\mathrm{pH}$.

The proportion of sucrose(-) Vibrio spp. were confirmed as V. parahaemolyticus, were significantly positively correlated with 'salinity. Sites yielding $\underline{V}$. parahaemolyticus isolates ranged in salinity

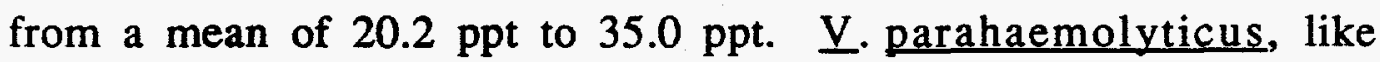

$2: \underline{V}$. vulnificus, was never isolated from LB or EBV which are coastal sites

$\therefore$ far removed from marsh lands and estuaries. The highest density of

$23 \mathrm{~V}$. parahaemolyticus was observed in BRC with a mean salinity of 20.2 ${ }^{24} \mathrm{ppt}$, a site which never yielded $\underline{V}$. vulnificus. The densities of ${ }^{25} \mathrm{~V}$. parahaemolyticus for the various sites ranged from $315 \mathrm{CFU} 100 \mathrm{ml}^{-}$ 
1 to $3.2 \times 10^{5} \mathrm{CFU} 100 \mathrm{ml}^{-1}$. In shellfish the densities of

: $\underline{\mathrm{V}}$. parahaemolyticus for $\mathrm{TL}$ and BR were $37.4 \mathrm{CFU} \mathrm{g}^{-1}$ and $207.6 \mathrm{CFU} \mathrm{g} \mathrm{g}^{-1}$

氵 respectively (Table 2). Significant positive correlations were observed

$\therefore$ between the percentage of $\underline{V}$. parahaemolyticus among sucrose(-) Vibrio

spp. and concentrations of phosphates and total phosphorus. Fecal

${ }^{6}$ coliform densities in the water column showed a significant positive

' correlation with densities of $\underline{V}$. parahaemolyticus (Table 3 ). The

Kanagawa pathogenicity test for $94 \%$ of $\underline{V}$. parahaemolyticus isolates

sesulted in identical hemolysis as the Kanagawa(+) control (ATCC

.17802 ). These results were confirmed on isolates sent to Charles A: Kaysner, Food and Drug Administration, Seattle. The percent

$=\underline{V}$. vulnificus and percent $\underline{V}$. parahaemolyticus among sucrose negative $\therefore$ Vibrio spp. was negatively correlated (Table 3 ). 


\section{DISCUSSION}

The density of fecal coliforms and Vibrio spp. in the water column

: was positively correlated with other pollution indicators in Puerto Rico

s waters, like phosphates, total phosphorus, and total bacterial counts,

and significantly negatively correlated with dissolved oxygen, and

' salinity. A highly significant positive correlation was observed between

${ }^{3}$ densities of Vibrio spp. and densities of fecal coliforms. Oliver et al.

(24) also observed a significant correlation between Vibrio spp. and fecal contamination in marine environments along the east coast of the United States.

Prior to this study the maximum density of Vibrio spp. reported in natural waters was in a temperate estuary, $10^{2}$ MPN ml-1 (14). The

- highest densities of Vibrio spp. observed in this study, a tropical estuary, were $1.5 \times 10^{6} \mathrm{CFU} \mathrm{ml}^{-1}$. The constant optimum growth temperature offered by a tropical climate may allow Vibrio spp. to stabilize at higher densities. The periodic drastic reduction in Vibrio spp. densities caused by winter $(14,16,32)$, would not be a regulating ${ }^{7}$ factor in a tropical estuary. The sucrose(-) vibrio population showed the same high density as did the total Vibrio spp. population. Kaneko and Colwell (15) report a sucrose(-) vibrio maximum density of 62.0

$\therefore$ CFU ml-1 in Chesapeake Bay. Bayamon River Channel estuary (BRC) had

i3 mean densities of sucrose(-) Vibrio spp. of $1.3 \times 10^{6} \mathrm{CFU} \mathrm{\textrm {ml } ^ { - 1 }}$. This

it could be a combination of both favorable temperature and a

${ }^{25}$ allochthonous source, eg., sewage. Fecal coliform densities at this site 
averaged $3.0 \times 10^{3} \mathrm{CFU} \mathrm{ml}^{-1}$. The significant positive correlation : between Vibrio spp. and fecal coliforms observed for all sites would support this observation. Other studies by our laboratory. $(3,7,11,17$, $-18,33)$ indicate that the survival of Vibrio spp. and other enteric

s bacteria in natural waters is much greater in the tropics.

6 Salinity appears to play a role in regulating sucrose(-) Vibrio spp. Densities of sucrose(-) Vibrio spp. and proportion of sucrose negative ₹ vibrios, were significantly negatively correlated with salinity. Oliver et al. (24) made similar observations for salinity and sucrose(-) vibrios from oysters. The negative effect that salinity has on densities of . $\underline{V}$. vulnificus follows the same pattern as that observed for sucrose(-) vibrios and sucrose(-) ONPG(+) vibrios. The frequency of ONPG(+) spp. among sucrose(-) Vibrio spp. may serve as an indicator of the presence of $\underline{\mathrm{V}}$ vulnificus. The highly significant negative correlation that this bacteria has with salinity is also suggested by a markedly reduced frequency of isolation from sites with increased salinity. Sites having salinities of 10 and $15 \mathrm{ppt}$ had both the highest densities of $\underline{V}$. vulnificus and the highest frequency of isolation among sucrose(-) vibrios. Kelly (16) also found that $\underline{\mathrm{V}}$. vulnificus was most frequently 30 isolated from sites where salinities ranged between 7 and 16 ppt.

$\therefore$ Tamplin et al. (32) reported the isolation of $\underline{v}$. vulnificus more 2 frequently in waters with a salinity greater than $17 \mathrm{ppt}$ and in a higher 23 proportion of samples greater than $23 \mathrm{ppt}$. The results of the present ${ }^{24}$ study do not corroborate those findings. $\underline{V}$. vulnificus was isolated only 25 from estuaries, and mangroves. Sandy beaches such as LB and EBV did 
not yield $\underline{V}$. vulnificus. Bayamon River estuary and the upper Río

Mameyes estuary which have extreme differences in salinities were ¿ sites of lowest isolation. Less than $4 \%$ of sucrose(-) isolates tested from : these sites resulted in positive identification. Considering that in vitro

s experiments have shown the optimum salinity ranges for $\underline{\underline{V}}$ vulnificus

${ }^{5}$ to be between 10 and $20 \mathrm{ppt}(16)$, it is understandable that these sites would not harbor this bacteria. The isolation of $\underline{V}$. vulnificus in

¿ Torrecilla Lagoon from water and shellfish only when salinities ranged

s between 20 and $25 \mathrm{ppt}$ also indicates it's low salinity requirements.

:0 When estimating the frequency of isolation of $\underline{V}$. vulnificus based $\therefore$ on the number of sucrose(-) vibrio isolates which were also ONPG(+) the

: frequency of isolation increases. Estimated in this manner, the

s percentage of $\underline{V}$. vulnificus obtained from all sites averaged $23 \%$. These

- results are comparable to those of Oliver et al. (24) who found $\underline{V}$. vulnificus represented $20 \%$ of all lactose $(+)$ sucrose(-) vibrios.

The highest densities of $\underline{V}$. vulnificus were obtained from Mandry Channel. Densities at this site averaged $4.1 \times 10^{3} \mathrm{CFU} 100 \mathrm{ml}^{-1}$ with $63 \%$ testing positive for pathogenicity. The detection of a $\underline{V}$. vulnificus

" mean density of $225 \mathrm{CFU} \mathrm{g}^{-1}$ shellfish in Torrecilla Lagoon further

ic suggests the importance of this bacteria as a probable agent of

$\because$ foodborne disease in Puerto Rico. In Torrecilla Lagoon, the percentage

22 of sucrose(-) vibrios that were $\underline{V}$. vulnificus was over three times

is greater in shellfish than in the over lying water column. The incidence 24 of $\underline{V}$. vulnificus; however, was not connected to sewage contamination, is since no correlation was observed with fecal coliforms. This organism 
appears to be an inhabitant of marine aquatic systems that are totally

$z$ unaffected by sewage effluent. This lack of association between

$\underline{V}$. vulnificus and fecal coliforms has also been noted in temperate areas $\therefore(23,24)$.

$5 \quad$ V.parahaemolyticus, unlike sucrose(-) vibrios, was positively correlated with salinity. This bacteria was found at sites with salinities between 20 and 35 ppt and was never isolated from sites with salinities ${ }^{3}$ less than $20 \mathrm{ppt}$. This would indicate that in the tropics higher salinities

' favor $\mathrm{V}$. parahaemolyticus; however, the highest density of this bacteria $\left(3.2 \times 10^{3} \mathrm{CFU} 100 \mathrm{ml}^{-1}\right)$ was detected at BRC, a site with a salinity of only 20.2 ppt. In contrast, PSC, 35 ppt salinity, harbored only

: $433 \mathrm{CFU} 100 \mathrm{ml}^{-1}$. An increase in salinity was also accompanied by a general decrease in the percentage of sucrose(-) vibrios that were

- confirmed as $\underline{V}$. parahaemolyticus. Intermediate salinities appear more favorable to this bacteria The fact that the organism was never isolated from sandy beaches indicates that although it can tolerate high salinity environments, it is an estuary and marsh inhabitant.

On the coast of West Africa (6), the lagoon system proved to be

${ }^{2}$ the most important reservoir of $\underline{V}$. parahaemolyticus. The seasonality

$\therefore$ observed in the incidence of this bacterium for West Africa was closely

$\therefore$ related to salinity. During the dry season, when isolation was most

$\therefore$ frequent, salinity of the lagoons was between 15 and $21 \mathrm{ppt}$. The rainy

23 season, which rendered lagoon salinity between 1.6 and $4.2 \mathrm{ppt}$ had the

${ }^{24}$ lowest incidence of $\underline{V}$. parahaemolyticus. These findings are in close

25 agreement to the present study. 
Maximum densities of $\underline{V}$. parahaemolyticus in this study were

z observed for Bayamon River Channel estuary $\left(3.2 \times 10^{7}\right.$ CFU $\left.100 \mathrm{ml}^{-1}\right)$.

: These elevated densities contrast markedly with those obtained for

- temperate estuaries. Kaneko and Colwell (14) report maximum

- densities of $400 \mathrm{CFU} 100 \mathrm{ml}^{-1}$ in Chesapeake Bay. They observed that

${ }^{6} \underline{\mathrm{V}}$. parahaemolyticus were undetectable until early June, when the

' water temperature was $19^{\circ} \mathrm{C}$. Watkins and Cabelli (35) also report far

${ }^{8}$ lower densities for Narragansett Bay, R.I. (495 CFU $100 \mathrm{ml}^{-1}$ ), than those

${ }^{9}$ recorded in this study. As in the case of total vibrios, high densities of

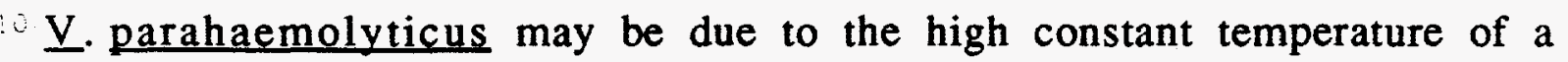
tropical climate and associated increased survival.

. Although previous studies conducted in the tropics did not quantify $\underline{V}$.parahaemolyticus, they did establish the presence of this

$\therefore$ bacterium in tropical waters and shellfish (21). In our study, densities in shellfish were found to be 37.4 and $207.6 \mathrm{CFU} \mathrm{g}^{-1}$. Although these levels are low in terms of the $10^{6}$ cell dose required to trigger gastroenteritis (29), they do bring to light the presence of this bacterium in shellfish harvested for local consumption. The possible "health hazard that these shellfish may represent is aggravated by the is typical handling they receive upon harvesting. The local practice of $\therefore$ selling shellfish at road side stands where there is no refrigeration $i$ would favor a marked increase in numbers of $\underline{V}$. parahaemolyticus ${ }^{23}$ present (4).

${ }^{24}$ The results of the present study demonstrated a significant ${ }^{25}$ positive correlation between fecal coliform levels and density of 
V. parahaemolyticus in the water column. Watkins and Cabelli (35) $:$ also reported a significant positive correlation between the level of fecal pollution and density of $\underline{V}$.parahaemolyticus. These authors observed : that it's densities decreased sharply with distance from the source of s fecal pollution. Maximum density of $\underline{E}$. coli recorded in their study was $=2.3 \times 10^{3} 100 \mathrm{ml}^{-1}$. Maximum density of fecal coliforms in the present study was recorded for Bayamon River Channel estuary, $3.0 \times 10^{5} \mathrm{CFU}$

${ }^{3} 100 \mathrm{ml}^{-1}$. Thus, the difference in densities of $\underline{V}$. parahaemolyticus ; between the tropical and temperate estuaries may be attributed not only to temperature differences but also to differences in levels of fecal contamination.

The present study indicates that $\underline{V}$. vulnificus and $\underline{V}$. parahaemolyticus behave distinctly in tropical waters. While one species is strongly associated with fecal contamination the other is not. In addition, both species appear to be strongly influenced by some of the same environmental factors, but with opposite effects. While highest densities of $\underline{v}$. vulnificus were obtained at low salinities, V. parahaemolyticus densities were greatest at high salinities. Phosphate and total phosphorus levels both were significantly correlated with densities of $\underline{V}$. vulnificus and $\underline{V}$. parahaemolyticus;

$\because$ however, like salinity these relationships were inverse. The differences

$\therefore$ observed indicate that these two organisms, although very similar,

23 occupy clearly separate niches in the tropical aquatic ecosystems. 


\section{ACKNOWLEDGMENTS}

:

: We thank Ronald Siebeling, Janet Simonson, and Luis Baéz of

- Louisiana State University for generously donating antiserum. Charles

${ }^{5}$ A. Kaysner, U. S. Food and Drug Administration, Seattle generously

${ }^{5}$ confirmed pathogenicity tests. Jésus Santiago provided technical

'assistance, while Gary A. Toranzos and Carl B. Fliermans made many

${ }^{z}$ helpful suggestions to the manuscript. This work was supported by a

' National Science Foundation predoctoral fellowship to Susan Rivera, and

$\therefore$ in part by Sea Grant R/LR-08-87-THA1 and Public Health Service grants RR-2657 and RR-8102 from the National Institutes of Health. In

$=$ addition, portions of the information contained in this article were

$\therefore$ developed during the course of work under Contract No. DE-AC09-

$\therefore$ 76SR00001 with the U. S. Department of Energy. 


\section{LITERATURE CITED}

1. Aiso, K., U. Shimidu, H. Katoh, K. Tatsumi, F. Sawada, and S. Katoh. 1963. Pseudomonas enteritis and related bacteria isolated from

$\leqslant$ seawater in the Pacific coast area. Ann. Rept. Inst. Food Micro. Chiba 6 Univ. 15:12-20.

2. American Public Health Association. 1985. Standard methods for 3 the examination of water and wastewater. 16th ed. American Public ; Health Association, Washington, D.C.

3. Biamón, E. J., and T. C. Hazen. 1983. Survival and distribution of Aeromonas hydrophila in near-shore coastal waters of Puerto Rico receiving rum distillery effluent. Water Res. 17:319-326.

4. Blake, P. A. 1984. Prevention of foodborne disease caused by Vibrio species, p. 579-591. In Colwell, R. R. (ed.), Vibrios in the Environment. John Wiley \& Sons, Inc., New York.

5. Blake, P. A., M. H. Merson, R. E. Weaver, D. G. Hollies, and P. C. Heublein. 1979. Disease caused by a marine vibrio. N. Engl. J. Med. $300: 1-5$.

6. Bockemühl, J., and A. Triemer. 1974. Ecology and epidemiology of :0 Vibrio parahaemolyticus on the coast of Togo. Bull. World Health $\therefore \quad$ Organ. 51:353-360.

¿ 7. Carrillo, M., E. Estrada, and T. C. Hazen. 1985. Survival and 23 enumeration of the fecal indicators Bifidobacterium adolescentis and 24 Escherichia coli in a tropical rain forest watershed. Appl. Environ. 25 Microbiol. 50:468-476. 
8. Center for Disease Control. 1971. Morbid. Mortal. Wkly. Rep. 20 (39):356.

9. Cherwonogrodzky, J. W., and A. G. Clark. 1982. Production of the Kanagawa hemolysin by Vibrio parahaemolyticus in a synthetic medium. Appl. Environ. Microbiol. 37:60-63.

6 10. Colwell, R. R., P. A. West, D. Maneval, E. F. Remmers, E. L. Elliot, and N. E. Carlson. 1984. Ecology of pathogenic Vibrios in Chesapeake

Bay, p. 367-387. In R. R. Colwell (ed.), Vibrios in the environment. $\cong \quad$ John Wiley \& Sons, Inc., N.Y.

11. Hazen, T. C., J. Santiago-Mercado, G. A. Toranzos, and M. Bermúdez. 1987. What do water fecal coliforms indicate in Puerto Rico ? a review. Bul. PR Med. Assoc. 79:189-193.

12. Hobbie, J. E., R. J. Daley, and S. Jasper. 1977. Use of Nuclepore filters for counting bacteria by fluorescence microscopy. Appl. Environ. Microbiol. 33:1225-1228.

13. Horie, S., K. Sakeki, and T. Okuzami. 1967. Quantitative enumeration of Vibrio parahaemolyticus in sea and estuarine waters. Bull. Jpn. Soc. Sci. Fish. 33:126-130.

14. Kaneko, T., and R. R. Colwell. 1973. Ecology of Vibrio

3 parahaemolyticus in Chesapeake Bay. J. Bacteriol. 113:24-32.

$\therefore$ 15. Kaneko, T., and R. R. Colwell. 1978. The annual cycle of Vibrio i2 parahaemolyticus in Chesapeake Bay. Microb. Ecol. 4:135-155.

23 16. Kelly, M. T. 1982. Effect of temperature and salinity on Vibrio 24 (Beneckea) vulnificus occurrence in a gulf coast environment. Appl. 25 Environ. Microbiol. 44:820-824. 
17. López-Torres, A. J., T. C. Hazen, and G. A. Toranzos. 1987. Distribution and in situ survival and activity of Klebsiella pneumoniae in a tropical rain forest watershed. Curr. Microbiol. 15:213-218.

s 18. López-Torres, A. J., L. Prieto, and T. C. Hazen. 1987. Comparison of 5 the in situ survival and activity of Klebsiella pneumoniae and Escherichia coli in tropical marine environments. Microb. Ecol.

8 15:1-16.

\$19. MacDonell, M. T., F. L. Singleton, and M. A. Hood. 1982. Diluent ii composition for use of API 20E in characterizing marine and estuarine bacteria. Appl. Environ. Microbiol. 44:423-427.

: 20. Miyamoto, Y., T. Kato, Y. Obara, S. Akiyama, K. Takizawa, and S. Yamai. 1969. In vitro hemolytic characterization of Vibrio parahaemolyticus: its close correlation with human pathogenicity. J. Bacteriol. 100:1147-1149.

21. Molitoris, E., S. W. Joseph, M. I. Krichensky, W. Sindhuhardja, and R. R. Colwell. 1985. Characterization and distribution of Vibrio alginolyticus and Vibrio parahaemolyticus isolated in Indonesia. Appl. Microbiol. 50:1388-1394.

$\because 22$. Oliver, J. D. 1981. Lethal cold stress of Vibrio vulnificus in oysters. 2 Appl. Environ. Microbiol. 41:710-717.

2: 23. Oliver, J. D., R. A. Warner, and D. R. Cleland. 1982. Distribution and 23 ecology of Vibrio vulnificus and other lactose-fermenting marine 24 vibrios in coastal waters of the south eastern United States. Appl.

25 Environ. Microbiol. 44:1404-1414. 
24. Oliver, J. D., R. A. Warner, and D. R. Cleland. 1983. Distribution of Vibrio vulnificus and other lactose-fermenting vibrios in the marine environment. Appl. Environ. Microbiol. 45:985-998.

25. Ortiz-Roque, C., and T. C. Hazen. 1987. Abundance and distribution of Legionellaceae in Puerto Rican waters. Appl. Environ. Microbiol. $53: 2231-2236$.

26. Poole, M. D., and J. D. Oliver. 1978. Experimental pathogenicity and mortality in ligated ileal loop studies of the newly reported halophilic lactose positive Vibrio sp. Infect. Immun. 20:126-129.

27. Rigau, J. G. 1986. Epidemiologic report. Department of Public Health, Commonwealth of Puerto Rico. December. San Juan, Puerto Rico.

28. Roberts, N. C., R. J. Siebling, J. B. Kaper, and H. B. Bradford. 1982. Vibrios in the Louisiana Gulf Coast environment. Microb. Ecol. $8: 299-312$.

29. Sakazaki, R., K. Tamura, T. Kato, Y. Obara, S. Yamai, and K. Hobo. 1968. Studies on the enteropathogenic, facultatively halophilic bacteria, Vibrio parahaemolyticus III. Enteropathogenicity. Jap. J. Med. Sci. Biol. 21:325-331.

30. Sayler, G. S., J. D. Nelson, Jr., A. Justice, and R. R. Colwell. 1976. Incidence of Salmonella spp., Clostridium botulinum, and Vibrio parahaemolyticus in an estuary. Appl. Environ. Microbiol. 31:723730 . 
31. Simonson, J., and R. J. Siebeling. 1986. Rapid serological identification of Vibrio vulnificus by Anti-H coagglutination. Appl. Environ. Microbiol. 52:1299-1304.

* 32. Tamplin, M., G. E. Rodrick, N. J. Blake, and T. Cuba. 1982. Isolation $s$ and characterization of Vibrio vulnificus in two Florida estuaries. 6 Appl. Environ. Microbiol. 44:1466-1470.

733. Valdés-Collazo, L., A. J. Schultz, and T. C. Hazen. 1987. Survival of 8 Candida albicans in tropical marine and freshwaters. Appl. Environ. э Microbiol. 53:1762-1767.

34. Wagatsuma, S. 1974. Ecological studies on Kanagawa phenomenon $\therefore \quad$ strains of Vibrio parahaemolyticus, p. . In T. Fujino, G. Sakaguchi, R. . $\quad$ Sakazaki and Y. Takeda (ed.), Saikon Publishing Co. Ltd. Tokyo.

35. Watkins, W. D., and V. J. Cabelli. 1985. Effect of fecal pollution on Vibrio parahaemolyticus densities in an estuarine environment. Appl. Environ. Microbiol. 49:1307-1313.

36. Zar, J. H. 1984. Biostatistical Analysis. Prentice-Hall Inc., Englewood Cliffs, N.J.

-37. Zimmermann, R., R. Iturriaga, and J. Becker-Birck. 1978. Simultaneous determination of the total number of aquatic bacteria, 2. and the number thereof involved in respiration. Appl. Environ. $\therefore \quad$ Microbiol. 36:926-934. 


\section{FIGURE LEGENDS}

$\hat{\imath}$

: Figure 1. Map of study sites around Puerto Rico.

- Figure 2. A: Density for Vibrio, fecal coliforms (FC), and total bacteria

5

6

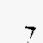

z

$$
\xi
$$$$
\text { ) }
$$$$
\therefore
$$$$
\text { i }
$$
(AODC) by site (mean \pm one standard error, $n=7$ ), B: Percent activity of total bacteria as measured by AODC (activity) and percent respiration as measured by INT (respiration) by site (mean \pm one standard error, $n=7$ ). 


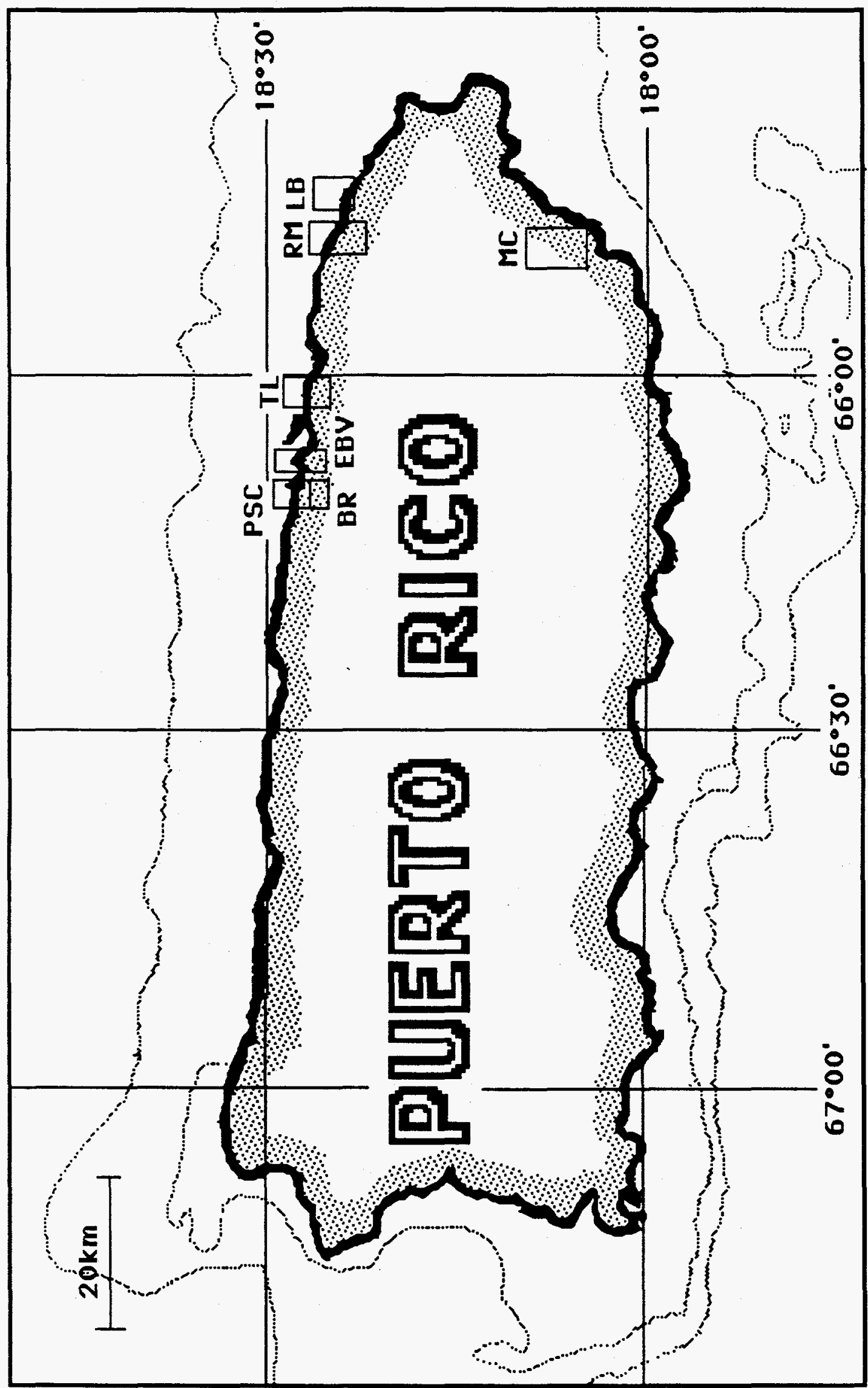



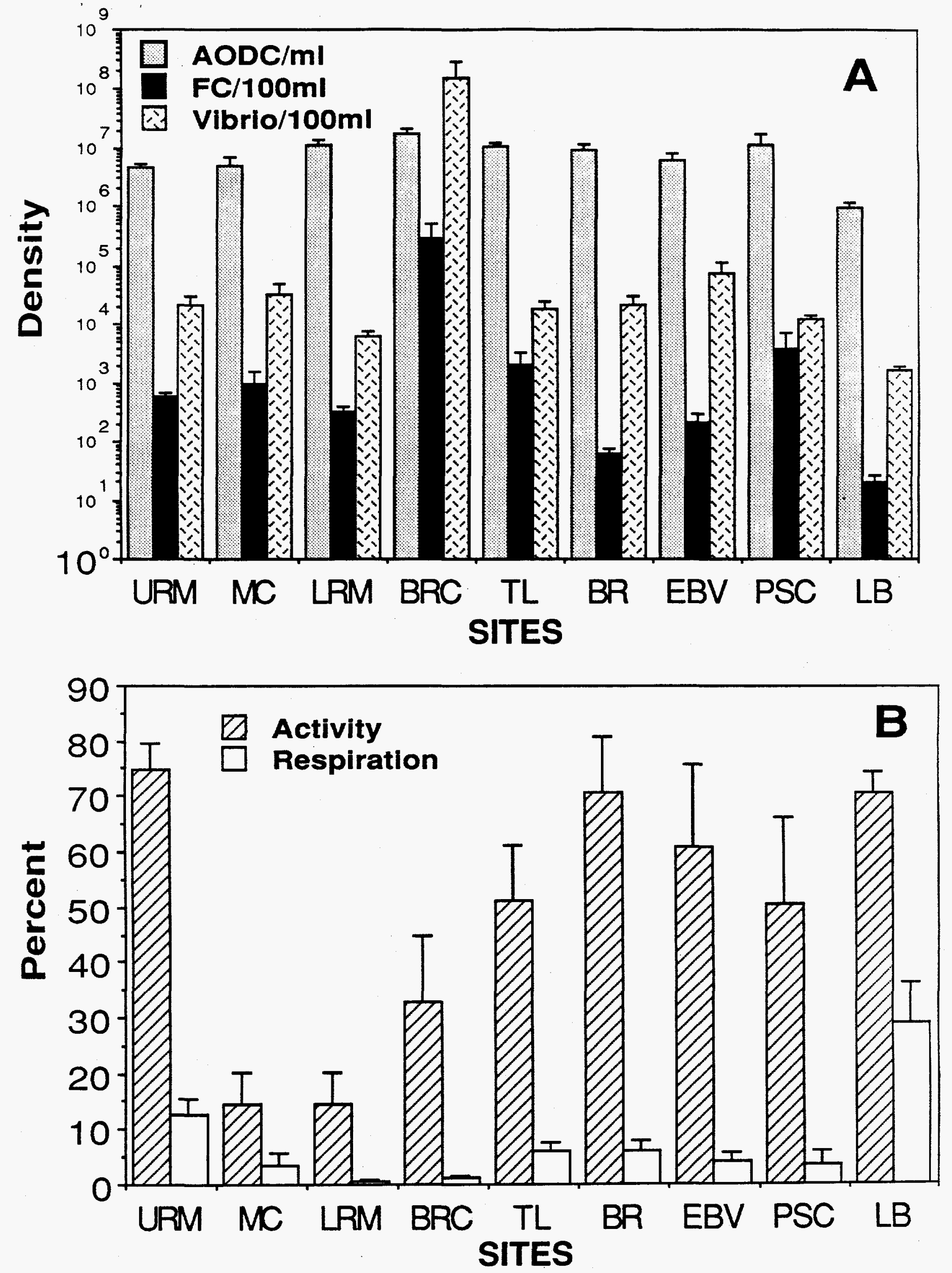
Table 1. Physical-Chemical Water Quality by Site

\begin{tabular}{|c|c|c|c|c|c|c|c|c|c|c|}
\hline Site & ATEMP & WTEMP & SAL & DO & PH & CHLA & TURB & $\mathrm{NO}_{3}$ & $\mathrm{PO}_{4}$ & TP \\
\hline URM & $27.0 \pm 0.5$ & $24.5 \pm 0.6$ & $1.7 \pm 0.0$ & $8.0 \pm 0.2$ & $7.2 \pm 0.1$ & $8.4 \pm 2.2$ & $96.3 \pm 1.4$ & $1.09 \pm 0.14$ & $0.030 \pm 0.003$ & $0.045 \pm 0.006$ \\
\hline MC & $30.1 \pm 0.0$ & $29.2 \pm 0.4$ & $8.0 \pm 1.3$ & $2.8 \pm 0.4$ & $7.3 \pm 0.1$ & $27.0 \pm 12.6$ & $95.9 \pm 0.8$ & $0.76 \pm 0.55$ & $0.029 \pm 0.011$ & $0.075 \pm 0.003$ \\
\hline LRM & $29.3 \pm 0.2$ & $27.8 \pm 0.5$ & $15.0 \pm 0.0$ & $5.1 \pm 0.7$ & $7.7 \pm 0.2$ & $1.7 \pm 0.4$ & $97.3 \pm 0.5$ & $0.53 \pm 0.12$ & $0.045 \pm 0.019$ & $0.051 \pm 0.01$ \\
\hline BRC & $30.7 \pm 0.9$ & $28.8 \pm 0.4$ & $20.2 \pm 0.4$ & $2.0 \pm 0.7$ & $7.9 \pm 0.1$ & $122.4 \pm 117.9$ & $96.0 \pm 0.9$ & $0.86 \pm 0.29$ & $0.423 \pm 0.086$ & $0.479 \pm 0.07 \gamma$ \\
\hline TL & $28.6 \pm 0.6$ & $26.9 \pm 0.6$ & $29.3 \pm 1.3$ & $7.7 \pm 2.0$ & $7.9 \pm 0.2$ & $30.1 \pm 6.9$ & $93.8 \pm 0.9$ & $0.59 \pm 0.18$ & $0.152 \pm 0.017$ & $0.219 \pm 0.016$ \\
\hline BR & $28.3 \pm 0.6$ & $28.7 \pm 0.4$ & $32.2 \pm 0.7$ & $5.7 \pm 0.6$ & $7.8 \pm 0.2$ & $7.5 \pm 1.2$ & $95.3 \pm 1.1$ & $0.30 \pm 0.06$ & $0.052 \pm 0.006$ & $0.085 \pm 0.012$ \\
\hline EBV & $25.7 \pm 0.6$ & $25.2 \pm 1.4$ & $34.8 \pm 0.5$ & $5.8 \pm 0.8$ & $7.0 \pm 0.5$ & $18.8 \pm 12.4$ & $94.5 \pm 1.4$ & $0.37 \pm 0.03$ & $0.048 \pm 0.013$ & $0.071 \pm 0.01$ \\
\hline PSC & $28.2 \pm 0.8$ & $32.5 \pm 1.0$ & $35.0 \pm 0.7$ & $6.3 \pm 0.5$ & $7.4 \pm 0.2$ & $3.7 \pm 1.1$ & $96.1 \pm 1.3$ & $0.53 \pm 1.25$ & $0.038 \pm 0.004$ & $0.053 \pm 0.00$ \\
\hline LB & $26.8 \pm 0.7$ & $25.7 \pm 0.6$ & $36.2 \pm 0.7$ & $6.9 \pm 0.4$ & $7.7 \pm 0.0$ & $11.8 \pm 2.4$ & $91.9 \pm 1.9$ & $1.75 \pm 0.80$ & $0.013 \pm 0.003$ & $0.018 \pm 0.00$ \\
\hline
\end{tabular}

*All values are mean \pm one standard error $(\mathbf{n}=7)$, ATEMP $=$ air temperature $\left({ }^{\circ} \mathrm{C}\right)$, WTEMP $=$ water temperature $\left({ }^{\circ} \mathrm{C}\right)$, DO

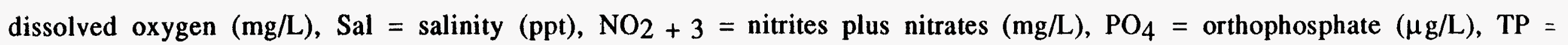
total phosphorus $(\mu \mathrm{g} / \mathrm{L})$, ChlA $=$ chlorophyll $a(\mathrm{mg} / \mathrm{L})$, TURB $=$ turbidity $(\%$ transmittance $)$. 
Table 2. Densities of bacteria by site.

\begin{tabular}{lcccc}
\hline Site & $\mathrm{V}$ & $\mathrm{S}(+)$ & $\mathrm{S}(-)$ & AODC \\
\hline URM & $213.3 \pm 92.2$ & $181.4 \pm 88.9$ & $27.00 \pm 5.26$ & $46.3 \pm 7.9$ \\
MC & $321.7 \pm 161.7$ & $235.9 \pm 147.6$ & $73.75 \pm 21.44$ & $49.6 \pm 19.1$ \\
LRM & $63.3 \pm 13.6$ & $40.5 \pm 9.8$ & $20.63 \pm 4.67$ & $111.0 \pm 33.0$ \\
BRC & $15.2 \pm 14.4$ & $2.4 \pm 1.8$ & $12.76 \pm 12.62$ & $173.0 \pm 39.6$ \\
TL & $189.0 \pm 56.5$ & $175.9 \pm 54.1$ & $10.51 \pm 4.61$ & $103.0 \pm 20.9$ \\
TL Shellfish & $5,169 \pm 1,521$ & $4,011 \pm 1,506$ & $1,271 \pm 725$ & $\mathrm{ND}$ \\
BR & $210.0 \pm 103.6$ & $173.9 \pm 78.3$ & $35.82 \pm 28.66$ & $90.3 \pm 26.1$ \\
BR - Shell fish & $14,625 \pm 25$ & $6,550 \pm 4,550$ & $2,700 \pm 800$ & $\mathrm{ND}$ \\
EBV & $746.3 \pm 386.5$ & $735.0 \pm 392.6$ & $16.67 \pm 8.70$ & $63.3 \pm 19.2$ \\
PSC & $126.7 \pm 14.5$ & $85.0 \pm 14.4$ & $32.50 \pm 6.29$ & $115.0 \pm 59.7$ \\
LB & $16.9 \pm 2.6$ & $13.8 \pm 2.7$ & $3.24 \pm 0.72$ & $9.6 \pm 2.1$ \\
\hline & & & & \\
\hline
\end{tabular}

All units are in CFU ml-1, except AODC which is $\mathrm{x} 10^{5}$ cells $\mathrm{ml}^{-1}$, shellfish values are CFI total Vibrio spp., $S(+)=$ sucrose positive, $S(-)=$ sucrose negative, AODC = Acridine Oran Counts, $\mathrm{FC}=$ fecal coliforms, $\mathrm{Vp}=$ Vibrio parahaemolyticus, $\mathrm{O}(+)=$ ONPG positive, $\mathrm{Vv}=$ vulnificus, $\mathrm{VvP}=$ pathogenic $\underline{\text { Vibrio }}$ vulnificus. 
Table 2. continued

\begin{tabular}{|c|c|c|c|c|c|}
\hline Site & FC & $V_{p}$ & $O(t)$ & $\mathrm{Vv}$ & VvP \\
\hline URM & $5.98 \pm 1.15$ & 0.00 & $20.54 \pm 4.00$ & $0.38 \pm 0.07$ & $0.38 \pm 0.07$ \\
\hline $\mathrm{MC}$ & $10.03 \pm 5.27$ & 0.00 & $65.12 \pm 18.92$ & $41.24 \pm 11.98$ & $26.06 \pm 7.57$ \\
\hline LRM & $3.20 \pm 0.78$ & 0.00 & $14.14 \pm 3.21$ & $3.23 \pm 0.73$ & $1.21 \pm 0.27$ \\
\hline BRC & $0.03 \pm 0.02$ & $3.20 \pm 3.16$ & $5.94 \pm 5.86$ & 0.00 & 0.00 \\
\hline$T L$ & $21.16 \pm 12.60$ & $3.15 \pm 1.38$ & $1.58 \pm 0.69$ & $0.53 \pm 0.23$ & 0.00 \\
\hline Tl Shell fish & $205.3 \pm 125.3$ & $37.4 \pm 21.3$ & $449 \pm 256$ & $225 \pm 128$ & $37.6 \pm 21.4$ \\
\hline BR & $0.62 \pm 0.12$ & $6.39 \pm 5.13$ & $10.23 \pm 8.19$ & $1.28 \pm 1.02$ & 0.00 \\
\hline BR Shellfish & $18.5 \pm 5.5$ & $207.6 \pm 61.5$ & $208 \pm 62$ & 0.00 & 0.00 \\
\hline EBV & $2.13 \pm 0.97$ & 0.00 & $3.85 \pm 2.01$ & 0.00 & 0.00 \\
\hline PSC & $39.70 \pm 30.14$ & $4.33 \pm 0.84$ & $2.16 \pm 0.42$ & 0.00 & 0.00 \\
\hline LB & $0.20 \pm 0.07$ & 0.00 & $0.83 \pm 0.19$ & 0.00 & 0.00 \\
\hline
\end{tabular}

see above 


\begin{tabular}{|c|c|c|c|c|c|c|c|c|c|c|c|c|}
\hline & WTEMP & ATEMP & SAL & DO & PH & CHLA & TURB & $\mathrm{NO}_{3}$ & $\mathrm{PO}_{4}$ & $\mathrm{TP}$ & V & $S(-)$ \\
\hline WTEMP & 1.000 & & & & & & & & & & & \\
\hline ATEMP & $\underline{0.465}$ & 1.000 & & & & & & & & & & \\
\hline $\mathrm{SAL}$ & 0.227 & -0.138 & 1.000 & & & & & & & & & \\
\hline DO & -0.052 & 0.138 & 0.288 & 1.000 & & & & & & & & \\
\hline PH & -0.036 & 0.020 & 0.243 & -0.301 & 1.000 & & & & & & & \\
\hline CHLA & -0.125 & -0.097 & 0.120 & 0.323 & -0.088 & 1.000 & & & & & & \\
\hline TURB & -0.211 & -0.233 & $-\underline{0.488}$ & -0.216 & -0.113 & -0.365 & 1.000 & & & & & \\
\hline $\mathrm{NO}_{3}$ & -0.012 & 0.098 & -0.137 & -0.252 & -0.028 & -0.047 & $\underline{0.386}$ & 1.000 & & & & \\
\hline $\mathrm{PO}_{4}$ & -0.318 & 0.046 & 0.368 & -0.096 & 0.322 & -0.048 & -0.186 & 0.196 & 1.000 & & & \\
\hline $\mathrm{TP}$ & -0.256 & 0.132 & 0.299 & -0.193 & $\underline{0.396}$ & 0.232 & $-\underline{0.403}$ & 0.095 & $\underline{0.885}$ & 1.000 & & \\
\hline V & -0.029 & 0.150 & -0.072 & -0.552 & 0.226 & -0.179 & -0.134 & 0.215 & $\underline{0.511}$ & 0.542 & 1.000 & \\
\hline$S(-)$ & 0.018 & -0.112 & -0.358 & -0.211 & -0.088 & -0.047 & 0.184 & -0.155 & -0.125 & -0.077 & 0.467 & 1.000 \\
\hline$S(+)$ & -0.040 & 0.143 & 0.028 & $-\underline{0.546}$ & 0.250 & -0.234 & -0.125 & 0.296 & $\underline{0.617}$ & $\underline{0.601}$ & $\underline{0.979}$ & 0.321 \\
\hline FC & -0.168 & 0.064 & -0.191 & $-\underline{0.476}$ & 0.410 & 0.131 & -0.134 & 0.022 & 0.330 & $\underline{0.460}$ & $\underline{0.766}$ & $\underline{0.501}$ \\
\hline AODC & -0.174 & -0.215 & $\underline{0.384}$ & 0.021 & 0.184 & -0.047 & $-\underline{0.479}$ & -0.387 & 0.140 & 0.127 & 0.161 & -0.003 \\
\hline vv & 0.046 & 0.108 & -0.761 & -0.217 & $-0,412$ & 0.026 & $\underline{0.488}$ & 0.212 & -0.536 & -0.420 & -0.165 & 0.326 \\
\hline$V_{p}$ & 0.059 & -0.110 & 0.111 & -0.169 & 0.153 & -0.020 & -0.167 & -0.258 & 0.217 & 0.245 & $\underline{0.646}$ & 0.821 \\
\hline$O(+)$ & -0.048 & -0.056 & -0.471 & -0.269 & -0.114 & -0.105 & 0.200 & -0.171 & -0.156 & -0.080 & $\underline{0.494}$ & $\underline{0.974}$ \\
\hline$\% S(-)$ & 0.062 & 0.041 & $-\underline{0.598}$ & 0.021 & -0.152 & 0.148 & 0.174 & -0.313 & -0.594 & $-\underline{0.439}$ & -0.005 & $\underline{0.745}$ \\
\hline$\% \mathrm{~V}$ & -0.001 & 0.081 & -0.060 & -0.376 & 0.212 & -0.132 & -0.137 & -0.050 & 0.368 & $\underline{0.419}$ & 0.889 & 0.720 \\
\hline$\% A$ & -0.246 & -0.528 & 0.234 & 0.120 & -0.040 & 0.332 & 0.343 & 0.236 & 0.147 & 0.008 & -0.240 & -0.236 \\
\hline$\% \mathrm{R}$ & 0.166 & -0.088 & 0.050 & 0.265 & -0.578 & 0.246 & 0.090 & 0.188 & -0.094 & -0.123 & -0.181 & -0.075 \\
\hline$\% O(+)$ & -0.136 & 0.269 & $-\underline{0.823}$ & -0.150 & -0.044 & -0.239 & $\underline{0.454}$ & -0.054 & -0.359 & -0.291 & 0.023 & 0.389 \\
\hline$\% V_{v}$ & 0.026 & 0.066 & -0.722 & -0.235 & -0.257 & -0.011 & $\underline{0.537}$ & 0.122 & -0.565 & -0.435 & -0.240 & 0.271 \\
\hline$\% \vee v P$ & -0.119 & -0.025 & $-\underline{0.838}$ & -0.086 & -0.391 & -0.084 & $\underline{0.476}$ & 0.101 & -0.614 & $-\underline{0.602}$ & -0.198 & 0.270 \\
\hline$\% V_{p}$ & 0.138 & 0.136 & 0.656 & 0.192 & 0.092 & 0.251 & -0.561 & -0.089 & 0.472 & $\underline{0.467}$ & 0.176 & -0.195 \\
\hline
\end{tabular}

where $p<0.05$ when $r>0.381$, underlined values are significant, see previous tables for abbreviations. 
Table 3. continued...

\begin{tabular}{|c|c|c|c|c|c|c|c|c|c|c|c|c|c|}
\hline & $S(+)$ & $\mathrm{FC}$ & $A O D C$ & $\mathbf{v}$ & $V_{p}$ & $O(+)$ & $\% \mathrm{~S}(-)$ & $\% \mathrm{~V}$ & $\% A$ & $\% \mathrm{R}$ & $\% 0(+)$ & $\% V_{v}$ & $\% \mathrm{~V} v \mathrm{P}$ \\
\hline$S(+)$ & 1.000 & & & & & & & & & & & & \\
\hline $\mathrm{FC}$ & $\underline{0.686}$ & 1.000 & & & & & & & & & & & \\
\hline AODC & 0.150 & 0.299 & 1.000 & & & & & & & & & & \\
\hline Vv & -0.248 & -0.100 & -0.492 & 1.000 & & & & & & & & & \\
\hline$V p$ & $\underline{0.548}$ & $\underline{0.613}$ & 0.278 & -0.241 & 1.000 & & & & & & & & \\
\hline$O(+)$ & 0.344 & $\underline{0.508}$ & -0.013 & $\underline{0.400}$ & $\underline{0.759}$ & 1.000 & & & & & & & \\
\hline$\% \mathrm{~S}(-)$ & -0.199 & 0.278 & -0.075 & $\underline{0.545}$ & $\underline{0.401}$ & $\underline{0.755}$ & 1.000 & & & & & & \\
\hline$\% \mathrm{~V}$ & $\underline{0.811}$ & $\underline{0.742}$ & 0.164 & -0.175 & $\underline{0.882}$ & $\underline{0.722}$ & 0.286 & 1.000 & & & & & \\
\hline$\% A$ & -0.175 & -0.151 & -0.185 & -0.210 & -0.147 & -0.345 & -0.290 & -0.259 & 1.000 & & & & \\
\hline$\% \mathrm{R}$ & -0.156 & -0.445 & -0.493 & 0.079 & -0.110 & -0.112 & -0.100 & -0.147 & $\underline{0.446}$ & 1.000 & & & \\
\hline$\% \mathrm{O}(+)$ & -0.175 & 0.101 & -0.412 & $\underline{0.724}$ & 0.064 & 0.519 & $\underline{0.616}$ & 0.102 & -0.425 & -0.206 & 1.000 & & \\
\hline$\% \mathrm{Vv}_{\mathrm{v}}$ & -0.320 & -0.125 & -0.548 & $\underline{0.942}$ & -0.269 & 0.352 & $\underline{0.529}$ & -0.216 & -0.207 & 0.005 & $\underline{0.759}$ & 1.000 & \\
\hline$\%$ VvP & -0.282 & -0.130 & -0.378 & 0.752 & -0.210 & 0.353 & 0.558 & -0.156 & -0.077 & 0.159 & 0.683 & 0.668 & 1.000 \\
\hline$\% V_{p}$ & 0.229 & 0.074 & 0.364 & -0.689 & 0.284 & -0.289 & $-\underline{0.405}$ & 0.180 & 0.226 & 0.179 & -0.762 & -0.767 & 0.603 \\
\hline
\end{tabular}

where $\mathrm{p}<0.05$ when $\mathrm{r}>0.381$, underlined values are significant, see previous tables for abbreviations. 
Table 4. Isolate Identification by Site

\begin{tabular}{lccccc}
\hline Site & $\mathrm{S}(-)$ & $\mathrm{O}(+)$ & $\mathrm{Vv}$ & $\mathrm{VvP}$ & $\mathrm{Vp}$ \\
\hline URM (water) & $26.6(71)^{*}$ & $76.1(54)$ & $1.41(1)$ & $100(1)$ & $0(0)$ \\
MC (water) & $46.4(34)$ & $88.2(30)$ & $55.9(19)$ & $63.2(12)$ & $0(0)$ \\
LRM (water) & $46.5(51)$ & $68.6(35)$ & $15.7(8)$ & $37.5(3)$ & $0(0)$ \\
BRC (water) & $37.1(56)$ & $46.4(26)$ & $0(0)$ & $0(0)$ & $25.0(14)$ \\
TL (water) & $8.0(40)$ & $15.0(6)$ & $5.0(2)$ & $0(0)$ & $30.0(12)$ \\
$\quad$ (shellfish) & $30.6(34)$ & $35.3(12)$ & $17.7(6)$ & $16.7(1)$ & $2.9(1)$ \\
BR (water) & $16.3(28)$ & $28.6(8)$ & $3.6(1)$ & $0(0)$ & $17.9(5)$ \\
$\quad$ (shellfish) & $18.5(13)$ & $7.7(1)$ & $0(0)$ & $0(0)$ & $7.7(1)$ \\
EBV (water) & $9.9(13)$ & $23.1(3)$ & $0(0)$ & $0(0)$ & $0(0)$ \\
PSC (water) & $26.8(15)$ & $6.7(1)$ & $0(0)$ & $0(0)$ & $13.3(2)$ \\
LB (water) & $21.8(54)$ & $25.9(14)$ & $0(0)$ & $0(0)$ & $0(0)$ \\
TOTAL & 409 & 190 & 37 & 17 & 35 \\
& & & & & \\
\hline
\end{tabular}

* Percent positive (No. of positive isolates), see previous tables for abbreviations. 